\title{
OS BISPOS CATÓLICOS E A DITADURA MILITAR BRASILEIRA.
}

DOI: http://dx.doi.org/10.15448/2178-3748.2018.1.26188

\author{
Bruno Dias Santos \\ Doutorando em História - UNESP \\ bruno.dias.santos@hotmail.com
}

GOMES, PAULO CÉSAR. Os bispos católicos e a ditadura militar brasileira: a visão da espionagem. Rio de Janeiro: Record, 2014

Passados mais de cinquenta anos do golpe civil-militar que inaugurou no Brasil os 21 anos de seu segundo regime autoritário, a historiografia, dentro das diversas temáticas relacionadas ao período, vive um momento de revisão e análise das versões produzidas, das categorias utilizadas e do papel exercido pela memória na constituição dos trabalhos acadêmicos e na formação do senso comum sobre a ditadura. Certamente, os marcos cronológicos - um deles acima destacado -, ensejaram essa iniciativa através da publicação de trabalhos de renomados historiadores e sociólogos como os de Rodrigo Patto Sá Motta, Marcelo Ridenti, Daniel Aarão Reis, Marcos Napolitano entre tantos outros. Também não se pode deixar de mencionar a importante contribuição dos debates suscitados pela iniciativa do governo brasileiro de criar a Comissão Nacional da Verdade, no ano de 2012.

O trabalho de Paulo César Gomes, "Os bispos católicos e a ditadura militar no Brasil", expressa claramente este desejo de parte da historiografia de, através de novas pesquisas e fontes, revisar categorias e concepções consagradas nos meios acadêmicos e interiorizadas pelas camadas não especializadas.

A importância da Igreja Católica na história político-cultural do Brasil, que se estende desde a chegada dos colonizados ao seu território, certamente não pode ser subestimada no período do regime militar, seu reconhecimento beira ao consenso, destacando-se seu papel de "porta-voz dos sem voz" e de defensora dos direitos humanos. Apesar de a instituição ter sido, de fato, a única que gozava de certa imunidade diante da ofensiva repressão estatal, e por isso, alguns dos membros de sua hierarquia terem se destacado em denúncias de torturas, do autoritarismo e da falta de liberdade, é preciso compreender a complexidade de sua estrutura interna, visto que, assim como qualquer instituição, ela não constitui um bloco monolítico sendo possível identificar nas ações de seus bispos posições distintas e até mesmo 
contraditórias. O posicionamento da própria instituição em relação ao regime, representado pela Conferência Nacional dos Bispos do Brasil (CNBB), atesta essa necessidade. Pouco tempo após o golpe, a instituição lançou um manifesto agradecendo aos militares por salvarem o país do perigo vermelho. Em menos de uma década, seus comunicados passaram a destacarem-se pelas críticas ao governo.

Gomes cumpre essa tarefa de diferenciação de maneira notável em seu trabalho. No primeiro capítulo, intitulado "Os bispos católicos e a ditadura militar", ele desenvolve uma análise da relação entre a Igreja e o Estado brasileiro que se inicia no século XIX e se torna mais pormenorizada ao abordar a segunda metade do século XX. Apesar de explorar a forte ligação entre as duas instituições, salientando que ela não se rompeu nem mesmo no auge de suas divergências, especialmente na década de 1970, essa constatação não constitui o seu foco principal.

O autor almeja evidenciar a aparente incongruência das ações e posicionamentos dos bispos brasileiros, para assim, reforçar a necessidade de uma abordagem mais atenta à sua complexidade. Procura demonstrar que categorias como "progressista" e "conservador" são demasiado estanques ou, em suas palavras, "estáticas", para se realizar esse empreendimento. Ele refuta as vertentes que interpretam essas ações como sendo frutos de uma simples filiação ideológica ou social, pois elas deveriam ser compreendidas a partir de princípios teológicos que não obedecem a uma lógica partidária. Por essa razão, o historiador toma como principal referência o livro Brasil: Igreja contra Estado, de Roberto Romano por considerá-lo como aquele que apresenta maior criticidade para romper com essa visão tradicional. O filósofo daria, segundo o autor, a devida importância ao discurso religioso evitando assim reduzir o posicionamento dos católicos às tendências econômicas ou mudanças políticas conjunturais.

O capítulo sugere que é de suma importância perceber que no seio da Igreja não há uma homogeneidade e que as categorias consagradas não passam de construções memorialísticas, portanto, feitas a posteriori. Embora a hipótese seja interessante, o autor não desenvolve uma argumentação que ateste sua conclusão em relação ao papel da memória nesse processo.

O segundo capítulo é o mais curto e nitidamente cumpre o papel de ligação entre as abordagens do primeiro e do terceiro. $\mathrm{O}$ autor apresenta um panorama do processo de montagem do sistema de informações do regime civil-militar. No entanto, mais do que simplesmente analisar de que maneira foi criado o Sistema Nacional de Informações (SNI), o modo pelo qual se deu a sua reformulação após o Ato Institucional n ${ }^{\circ} 5$, como foram criadas 
suas Divisões de Segurança e Informações (DSIs) e os Destacamentos de Operações e Informações (DOI), é nítida a sua abordagem revisionista.

Gomes se esforça continuamente por desmistificar as concepções construídas $a$ posteriori sobre a ditadura e suas diversas maneiras de atuação, o que não corresponde, obviamente, a justificá-las. Logo no início, ele faz questão de afirmar que experiências como a espionagem, a polícia política, a censura e os órgãos de propaganda já existiam ou haviam sido praticadas no período republicano brasileiro, anterior a 1964. Entre outras questões, é bastante destacada nessa seção a crítica ao juízo de que existia uma uniformidade ideológica e operacional nas forças armadas. $\mathrm{O}$ autor faz questão de sublinhar que muitas tendências que dividiam os militares e a historiografia especializada já contam com renomadas referências que analisam e interpretam esses assuntos. Também se contrapõe à versão de que a repressão seria um rebento do AI-5; novamente ele afirma ser esta uma visão construída a posteriori por aqueles que levantavam a bandeira de que general Castelo Branco era um democrata avesso ao arbítrio. Para comprovar a fragilidade dessa visão, o historiador elenca exemplos de autoritarismo e repressão imediatamente exercidos após o golpe de 1964.

$\mathrm{Na}$ seção "Os bispos católicos e a comunidade de informações", Gomes faz uma análise minuciosa das informações produzidas pelas DSIs sobre os bispos brasileiros. Ele procura demonstrar como a tarefa dos analistas é complexa neste caso. Isto se deve principalmente, em sua visão, a dois fatores: o poder simbólico do qual goza a Igreja e o longo histórico de sua íntima relação com o Estado brasileiro. Desta forma, apesar de deixarem patente como os membros da hierarquia eram subversivos em suas ações e declarações, dificilmente esses processos chegavam a motivar o acionamento dos órgãos de repressão; em sua maioria, eles eram arquivados.

O autor também procura apontar que essa complexidade é perceptível por outras características. Se por um lado, parte do episcopado era rotulado como tendo sido afetado pelo comunismo, não há repreensão ao aspecto moral. Ou seja, apesar das divergências entre os bispos quanto ao papel da Igreja nas questões político-sociais, existia um consenso quanto a temas comportamentais como aborto, amor livre e o divórcio. Outra dificuldade dos analistas era compreender as atitudes tomadas por determinados bispos, por considerá-las destoantes de seus posicionamentos pregressos. Também, é bastante explorada pelo historiador, a fixação que os órgãos de informação tinham por alguns bispos em especial; o capítulo se detém longamente sobre os dois exemplos mais simbólicos: Dom Helder câmara, reconhecido como um inimigo poderoso da ditadura por denunciar o autoritarismo e a tortura internacionalmente; e Dom Pedro Casaldáliga, bispo catalão da prelazia de São Félix do 
Araguaia no Mato Grosso, reconhecido pela defesa dos pequenos agricultores e dos indígenas, ação que desde a sua chegada à região incomoda os empresários e fazendeiros, rendendo-lhe inúmeras ameaças de expulsão do país, por parte do governo, e de morte pelos poderosos da localidade.

Sem dúvida, o trabalho de Paulo César Gomes é uma contribuição importantíssima à historiografia sobre o regime civil-militar brasileiro e, especificamente, sobre as atividades desenvolvidas pela comunidade de informação nesse período. Sua abordagem demostra-se bastante consciente quanto à complexidade desse momento histórico do Brasil e das instituições envolvidas. O que se destaca, majoritariamente, em sua percepção sobre os posicionamentos dos bispos católicos que é de grande relevância para os argumentos elencados no livro, é que eles ultrapassam enormemente a simples filiação ideológica. O mesmo se pode dizer em relação às forças armadas. O autor reafirma constantemente que a instituição não é um bloco homogêneo, além de refutar sobremaneira uma leitura maniqueísta. No entanto, também é necessário mencionar que, apesar da clareza com que o historiador aponta o papel da memória na construção de um senso comum sobre o período, ele trata as concepções edificadas por esse processo como simples erros de análise, deixando assim de abordar as implicações político-discursivas que, em um contexto de abertura e redemocratização, moldaram sua produção.

RESENHA ENVIADA EM: 28/01/2017

RESENHA ACEITA PARA PUBLICAÇÃO EM: 10/05/2017 